\author{
CĂTĂLINA Mititelu \\ Ovidius University of Constanta, Romania \\ (D) https://orcid.org/0000-0001-6489-9252
}

\title{
The Council of Metropolitan See and Its Canonical Basis An Orthodox Approach
}

\begin{abstract}
In this canonical study, the reader of the article will have an opportunity to become acquainted with an old European canonical-juridical institution, that is, the synodality, and, ipso facto, about its juridical regime. And, naturally, the reader can get acquainted more closely with the provisions of the canonical norms of the Eastern Church regarding the eparchial (metropolitan) synodality institution, and, ipso facto, with the issue of the regime of the synodality.

Since the canonical bases of the synodality regime are foreseen in the canonical legislation of the first millennium, we had to make an hermeneutical analysis of its text, which showed us that, by resorting to ad fontes, we can also pave the way that would go towards the restoration of the unity of the two Christian worlds, namely, Pars Orientis and Pars Occidentis.
\end{abstract}

Keywords: canonical legislation, canonical-juridical institutions, the ecumenical councils

\section{Introduction}

Since even in our days there are some theologians, ecclesiologians, church historians and canonists who are speaking about the so-called crisis of synodality, we considered that it is important to deal with this topic, that is, the institution of the synodality, which took a new form of manifestation due to the administrative reform undertaken by Emperor Diocletian (284-305), when the bishoprics of the Roman Empire prov- 
inces had to adjust their administrative-territorial organisation in the framework of the Roman provinces. Consequently, the hierarch of the province's capital, the basic unit of the administrative-territorial system of the Roman Empire, would become the leader ${ }^{1}$ of the local Churches in that geographical area.

The 'protos' ( administrative-territorial unit of the Roman Empire, that is, the province, continued to bear the title of archbishop, proto-hierarch, or prima cathedra episcopalis (bishop of the first See) (can. 58, Sin. Elvira, 306). ${ }^{2}$

Since the present article will make references only to the Council of Metropolitan See - from the Orthodox viewpoint - our main goal is to offer to our lecturer not only a better understanding of its canonical basis, but also to prove that the system of the metropolitan synodality is still functioning in the Eastern Church, as it is in fact proved peremptorily both by the canonical legislation of these Churches, and by their Statutes and their own administrative-territorial organisation.

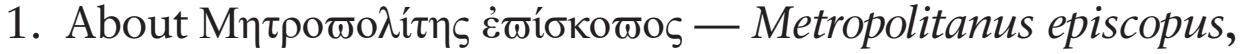 the bishop of the Roman metropolis of each Roman province, and his canonical prerogatives}

The "Metropolitan", that is, the bishop of the capital of the province, ${ }^{3}$ would impose himself on the church lexicon "once with the adoption and implementation of the decision of the first Ecumenical Council (Nicaea, 325)," ${ }^{4}$ taken by can. 4. According to it, the bishops of a province of the Roman Empire were grouped in its geographical area, "led by a council consisting of all the bishops of the province under

${ }^{1}$ N. V. Dură: The Primate in the Orthodox Church. Canonic Study (Întâistătătorul în Biserica Ortodoxă. Studiu canonic). "Studii Teologice", XL, 1 (1988), pp. 15-50.

2 The text of the canon 58 of the Synod of Elvira dealt with the "Bishop of the First Church See in Spain", that is, the Primate of a local Church, constituted within a well-defined ethnic and geographic framework (N. V. Dură: Le Régime de la synodalité selon la législation canonique, conciliaire, oecuménique, du Ier millénaire, Ed. Amethyst 92, Bucharest, 1999, pp. 939-940).

3 See N. V. DurĂ: Le Régime de la synodalité..., pp. 415-417; 421-437.

${ }^{4}$ IDEm: "Scythia Mynor" (Dobrudja) and her Apostolic Church. The Archiepiscopal and Metropolitan See of Tomis (4th-14th centuries) („Scythia Mynor” (Dobrogea) şi Biserica ei apostolică. Scaunul arhiepiscopal şi mitropolitan al Tomisului (sec. IV-XIV)). Ed. Didactică şi Pedagogică, Bucharest, 2006, p. 83. 
the presidency of the Metropolitan, i.e. the Bishop of the capital of the province." 5

As for the "Synod of Bishops" in the Church province, namely, the epar-

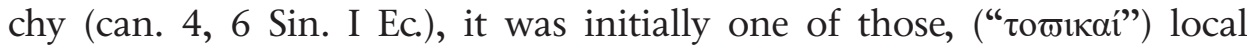
councils, ${ }^{6}$ that is, of a local Church organised within an ethnic and geographical framework from the apostolic age (cf. can. 34 apost.), as was the case with the Churches of the Roman provinces, as, for example, Scythia Minor (today's Dobrudja), whose Episcopal See was founded by St. Apostle Andrew at the ancient Tomis city (today's Constanța), which would become the capital of the province that the Romans had conquered in $27 \mathrm{BC}$.

However, it is noteworthy that since the pre-Nicene era, local Churches had been established outside the boundaries of the Roman Empire. The case of the Churches in Ethiopia, ${ }^{7}$ Georgia, ${ }^{8}$ Persia, Armenia, etc. remains, surely, conclusive and edifying in this respect. Where the institution of synodality was indeed present in the life of these local Churches, based on the same principle of synodality set forth by our Saviour Jesus Christ and affirmed by His Holy Apostles.

By the Milan' ${ }^{9}$ edict of 313, the Christian religion became a Religio licita, that is, 'permitted Religion'. And after this Edict most of these

${ }^{5}$ Comment on Canon 4 of the First Ecumenical Synod, in The Canons of the Orthodox Church. Notes and comments (Canoanele Bisericii Ortodoxe. Note şi comentarii), ed. I. N. Floca, Sibiu, 1991, p. 51, n. 2.

6 N. V. Dură: Le Régime de la synodalité..., p. 422.

7 See N. V. DuRĂ: The Organization of the Ethiopian Church and its Canonical Foundations (Organizarea Bisericii etiopiene şi bazele ei canonice), Ed. IBMBOR, Bucharest, 1990; IDEM: The Ethiopian Canonical Collection (Corpus Juris Canonici Aethiopici) (Colecția canonică etiopiană (Corpus Juris Canonici Aethiopici)). "Studii Teologice", XXVI, 9-10 (1974), pp. 725-738; IDEM: The Appropriation of the Canons in the Ethiopian Church (Receptarea canoanelor în Biserica etiopiană). "Studii Teologice", XXVII, 3-4 (1975), pp. 277-289; IDEm: Didascalia, the Ethiopian Version (Didascalia, versiunea etiopiană). "Studii Teologice", XXVII, 5-6 (1975), pp. 436-451; IDEm: The Church of Alexandria and the Canonical-Pastoral Activity of its Hierarchs until the Council of Chalcedon (Biserica Alexandriei şi activitatea canonico-pastorală a ierarhilor ei până la Sinodul de la Calcedon) (451). "Studii Teologice", XXXIII, 1-2 (1981), pp. 5-25; IDEM: The Coptic Church and its Organization in Light of the Testimonies of the Historical-Aghiographic Tradition (Biserica Coptă şi organizarea ei în lumina mărturiilor Tradiției istorico-aghiografice). "Studii Teologice", XXXIV, 3-4 (1982), pp. 200-219; IDEM: The Ethiopian Church and its Liturgical Anaphoras (Biserica etiopiană şi „Anaforalele” ei liturgice). "Revista de Teologie Sfântul Apostol Andrei”, XII, 1 (2008), pp. 9-45.

${ }^{8}$ See G. Kvesitadze, N. V. Dură: The Roots of the Georgian and Romanian Science and Culture, Ed. Academiei Oamenilor de Ştiință din România, Bucharest, 2017, pp. 11, $19-61$.

${ }^{9}$ See N. V. Dură: The Edict of Milan (313) and its Impact on the Relations between the State and the Church. Some Historical, Legal and Ecclesiological Considerations (Edictul de la Milan (313) şi impactul lui asupra relațiilor dintre Stat şi Biserică. Câteva considerații 
local Churches - many of apostolic origin - would be part of the Christian area within the Roman Empire, designated by the notion of oekoumene (the universe of the Christian world), whose ecumenical unity would be defined by the ecumenical councils. ${ }^{10}$

Enjoying the protection of Christian Emperors, ${ }^{11}$ these local Churches had both the possibility to accommodate their form of administrativeterritorial organisation to that of the Roman State and to affirm the principle of synodality, as stated by the Founder of the Church and affirmed by His Apostles.

From the First Ecumenical Synod - held with the support of the imperial power, that is, Emperor Constantine the Great - the Synod of

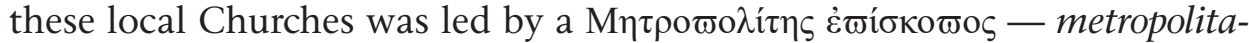
nus provinciae ${ }^{12}$ (can. 4, 6 Sin. I Ec.; 3, 6 Sin. II Ec.; 1 Sin. III Ec.), that is, a Metropolitan bishop, whose See was in the Roman metropolis of each province (eparchy).

From a sacramental perspective, this Metropolitan bishop held noth-

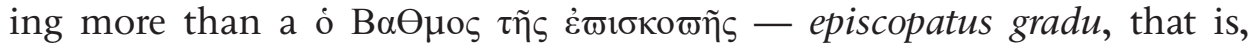
'a bishop's rank'. ${ }^{13}$ What distinguished the bishop of the province's metropolis from his peers in the episcopate was merely his status of primus inter pares, but he was entitled - according to the can. 4 of the First Ecumenical Council (Nicaea, 325), whereby the system of the ecclesiastical administrative-territorial organisation was adopted - to "strengthen" or to confirm the election and the ordination of bishops of the "eparchy," committed however "by all the bishops" (can. 4 Sin. I Ec.).

istorice, juridice şi ecleziologice). "Mitropolia Olteniei”, 5-8 (2012), pp. 28-43; N. V. DurĂ, C. Mititelu: The Freedom of Religion and the Right to Religious Freedom. In: SGEM Conference on Political Sciences, Law, Finance, Economics \& Tourism, I (2014), Albena, pp. 831-838.

${ }^{10}$ See N. V. Dură: Christianism in Pontic Dacia. The "Scythian Monks" (DacoRoman) and their Contribution to the Advance of Ecumenical Unity and the Development of the European Christian Humanist Culture. "Revue Roumaine d'Histoire", 1-4 (2003), pp. 5-18; IDEM: The Churches of Europe and the "European Union". Ecumenism, Christian Reconciliation and European Unity (Bisericile Europei şi „Uniunea Europeană”. Ecumenism, reconciliere creştină şi unitate europeană). In: Biserica în misiune. Patriarhia română la ceas aniversar, Ed. IMBOR, Bucharest, 2005, pp. 771-794; C. Mititelu: Dacian-Roman Cultural Personalities from Scythia Minor (4th-6th Centuries) and their Contribution to the Affirmation and Promotion of a Humanistic-Christian Culture at European Level. In: New Approaches in Social and Humanistic Sciences, 2018, Iasi-London, ed. V. Manolachi, C. Rus, S. Rusnac, pp. 316-331.

${ }^{11}$ See N. V. Dură: The Relationships between the State and the Church and their Legal Regime. Rules of International and National Law. "Bulletin of the Georgian National Academy of Sciences", XII, 4 (2018), pp. 192-201.

${ }^{12}$ N. V. Dură: Le Régime de la synodalité..., pp. 422-423.

13 Ibidem, p. 423. 
The "Arabic version" of the canons, "attributed to the Council of Nicaea" (325), acknowledge also the fact that Metropolitan bishop was entitled to confirm both "the election of a bishop" and his "ordination" (can. 5). ${ }^{14}$ In other words, not only the confirmation of the newly elected bishop was the right of the Metropolitans of provinces (cf. can. 4 Sin. I. Ec.), but also the confirmation of the ordination of any bishop of his province. Indeed, the metropolitanus provinciae had to confirm both the election and the ordination of a bishop, as the Holy Fathers of first Ecumenical Council decided in the canon forth.

In fact, about this reality give us a peremptory testimony not only the Byzantine canonists, but also some western canonists. For example, John Zonara (12th century) precised that "the election has to be ratified by the metropolitan of the province," 15 and, according C. J. Hefele, in the canon 4 the Fathers of the Council of Nicaea decided that the elected bishop has to be approved by "the metropolitan," confirming thus "the superior position of the metropolitan," 16 which was "connected with $[\ldots]$ the provincial synod," mentioned indeed, expressly, in "the next canon," 17 that is, the can. 5 of the First Ecumenical Council.

Concerning the ordination of the bishop, this sacramental act was accomplished by the members of the eparchial synod, as even the Metropolites "were ordained - testimony Balsamon - by their own synods," 18 which had to be held "twice a year" (can 5 Sin. I. Ec.). In fact, the "Arabic" version of the canons, attributed to the First Ecumenical Council, confirm the fact that the "provincial Councils" "should be held twice a year [...]" (can. 7). ${ }^{19}$

${ }^{14}$ Apud Select Library of the Nicene and Post-Nicene Fathers of the Christian Church, ed. P. SChaff and H. WACE, 2nd series, vol. 14, SAGE Software Albany, Oregon, 1996, p. 154 (apud http://www.agape-biblia.org/orthodoxy/The\%20Seven\%20Ecumenical\%20 Councils.pdf).

15 The Syntagma of the Divine and Sacred Canons (Athenian Syntagma), ed.

G. A. Rhalli, M. Potli, vol. II, Atena, 1852, pp. 122-123.

${ }_{16}$ Select Library of the Nicene and Post-Nicene Fathers..., p. 74.

17 Ibidem, p. 75.

18 Ibidem, p. 467.

19 Ibidem, p. 154. 
2. The Synod of the bishops of each diocese (bishopric) and its canonical basis

From the text of the canonical legislation of the Eastern Church, one can learn that there were two types of synods that characterised the first millennium, that is, the "metropolitan synod and the patriarchal synod. But, by far, the favourite was the metropolitan Synod," due to the fact that both the Ecumenical Synods and the local ones provided precise norms and regulations not only concerning the convening and composition of this type of synod, but also the "nature of its synodal debates etc." 20

A first testimony regarding the (metropolitan) eparchial Synod is given to us by the apostolic can. 37, although it did not yet bear the name of Metropolitan Synod, that is, of the Church province, but of a local Church constituted within a well-defined ethnic framework. Indeed, in the text of this apostolic canon - enacted probably by a Synod of the Antiochian Church at the end of the 3rd century - reference is made only to

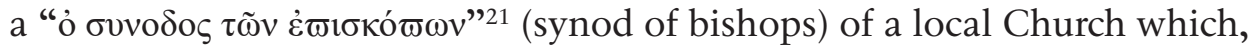
following the administrative-territorial reform of the Roman Empire, initiated by Emperor Diocletian in 284-285, circumscribed not only by an ethnically well-defined area (cf. can. 34 apost.), but also by a geographical one.

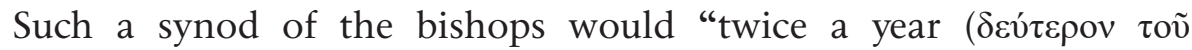

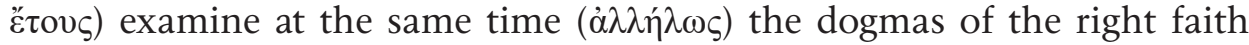

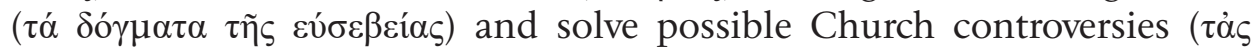

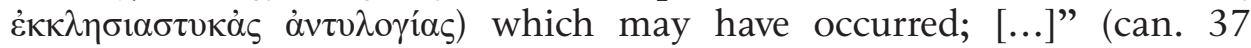
apost.). ${ }^{22}$

In their comment on the apostolic can. 37, the Byzantine canonists,

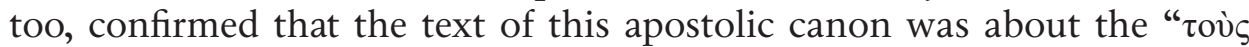

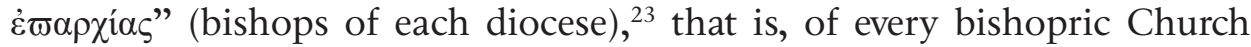
of the province (eparchy).

This canon attributed to the Holy Apostles remains - above all — an obvious testimony to the affirmation of the principle of synodality "as a basic principle of Church organisation and leadership," which was stated ever since the "Apostolic Age." ${ }^{24}$ As a matter of fact, the provision of principle of the apostolic can. 37 "has constantly been applied"

\footnotetext{
${ }^{20}$ N. V. Dură: Le Régime de la synodalité..., p. 421.

${ }^{21}$ Apud Athenian Syntagma, vol. II..., p. 50.

22 Ibidem.

${ }^{23}$ Ibidem, pp. 50, 52.

${ }^{24}$ The Canons of the Orthodox Church (Canoanele Bisericii Ortodoxe)..., 1991, p. 27.
} 
not only to the (eparchial) provincial, metropolitan type of synods, but "also to the synods of autocephalous or autonomous Churches, organised on larger territories than a single province. Thus - as concluded by an Orthodox canonist — it still applies today."25

3. The territorial principle, one of the main canonical principles of the administrative-territorial organisation

By adapting the form of ecclesiastical, administrative-territorial organisation to the one of the Roman State, the Church actually voiced and stated in the text of its legislation (cf. can. 4, 6 Sin. I Ec.) the territorial principle, ${ }^{26}$ that is, one of its fundamental canonical principles, which was then reaffirmed by can. 17 of the Fourth Ecumenical Synod and canon 38 of the Sixth Ecumenical Synod (Trullan).

According to the can. 17 of the Fourth Ecumenical Synod, the

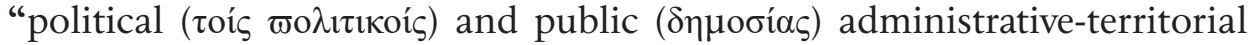
units must be followed by the organisation of church units," or in the terms used by the Byzantine commentators of this canon, the "political"

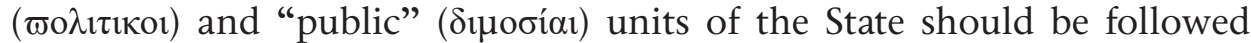

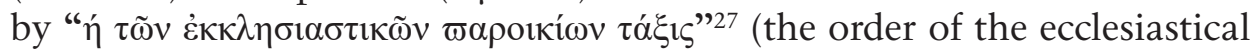
bishoprics).

This canonical provision stated by the Fathers of the Fourth Ecumenical Synod - which gives an evident testimony regarding the continuation of the process of adapting the forms of the administrative-territorial organisation of the Church to that of the State - would be reiterated and confirmed by the Fathers of the Sixth Ecumenical Synod, which decided that "the order of the ecclesiastical things follow the civil and public models" (can. 38).

Thus, it was reaffirmed and renewed the "old principle," that is, the territorial principle, according to which "church organisation must also

${ }^{25}$ Ibidem, p. 28.

${ }^{26}$ See details in N. V. DurĂ: The Canonical, Fundamental, Organizing and Functioning Principles of the Orthodox Church and their Reflection in the Legislation of the Romanian Orthodox Church (Principiile canonice, fundamentale, de organizare şi funcționare a Bisericii Ortodoxe şi reflectarea lor în legislația Bisericii Ortodoxe Române). "Revista de Teologie Sfântul Apostol Andrei”, V, 9 (2001), pp. 129-140.

${ }^{27}$ I. Zonara: Comment on canon 38 of the Trullan Synod. In: Athenian Syntagma..., vol. III, Atena, 1853, p. 262. 
take into account state organisation, i.e. to adapt to it, so that within the administrative-territorial units of the state those of the Church would also organise." 28

By realising the process of adapting the organisation of the church administrative-territorial units to those of the (Roman) State, not only the canonical foundations of the organisation of the local Churches in the geographical area of the Roman provinces were laid, but also those of the canonical status of the bishop of the metropolis, that is, of the metropolitan, whose exponential role remained that of being the president of the supreme collegial-synodal governing body of the diocese, that is, the Metropolitan Synod, to which any bishop could appeal, since according to canon 17 of Council of Chalcedon (451), "it is lawful for those who hold themselves aggrieved to bring their cause before the synod of the province." 29

Anyhow, it must be emphasised and borne in mind that a metropolitan type of organisation, with its synodal form, did not disappear even after the Church adopted a new form of administrative-territorial organi-

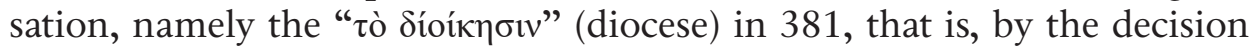
taken by the Fathers of the Second Ecumenical Synod (cf. can. 3 and 6).

Indeed, the Fathers of this Synod clearly ordered "that the issues con-

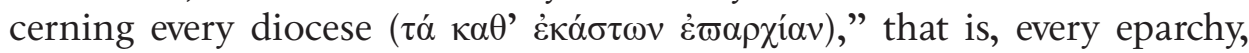

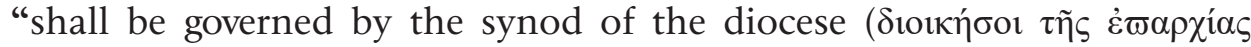

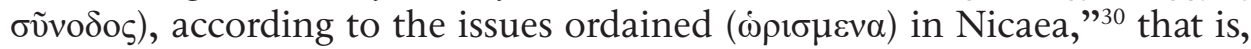
the First Ecumenical Synod, assembled in Nicaea in 325, by canons 4, 5, 6 , and 7.

\section{The frequency of the eparchial (metropolitan) Synod and its canonical basis}

The Fathers of the First Ecumenical Synod (Nicaea) were indeed those who also stipulated the obligation of the eparchial (metropolitan) Synod to meet "twice a year, in order that $[\ldots]$ all the bishops of the province, [...] assembled together," to examine if a person has been "excommunicated through captiousness, or contentiousness, or any such like ungracious disposition of the bishop" (can. 5). ${ }^{31}$

${ }^{28}$ The comment of can, 38 of the Sixth Ecumenical Synod (Trullan, 691/692). In:

The Canons of the Orthodox Church (Canoanele Bisericii Ortodoxe)..., 1992, p. 127.

29 Select Library of the Nicene and Post-Nicene Fathers..., p. 689.

${ }^{30}$ Athenian Syntagma..., vol. II, p. 70.

${ }^{31}$ Select Library of the Nicene and Post-Nicene Fathers..., p. 77. 
This provision of principle, that is, that in every province (eparchy) the provincial synods shall be held twice a year, it was reiterated and renewed by the Fathers of the Fourth Ecumenical Synod (Chalcedon, 451) in the can. 19, who claimed that "according to the canons of the Holy Fathers, [...], the [...] Synods of Bishops, [...], shall twice in the year assemble together where the bishop of the Metropolis shall approve, and shall then settle whatever matters may have arisen" (can. 19). ${ }^{32}$

In ancient Epitome of this can. 19 of the Fourth Ecumenical Council (Chalcedon, 451), it was written that "twice each year the Synod shall be held where ever the bishop of the Metropolis shall designate, and all matters of pressing interest shall be determined." 33 But, in another ancient Epitome of can. 5 of the First Ecumenical Council, it was already underlined the fact that "there has always been found the greatest difficulty in securing the regular meetings of provincial and diocesan synods, [...], despite the very explicit canonical legislation upon the subject [...]." 34

Indeed, due to the 'invasions of barbarians' ( $\tau \grave{\alpha} \tau \tilde{\omega} v \quad \beta \alpha \rho \beta \alpha ́ \rho \omega v$

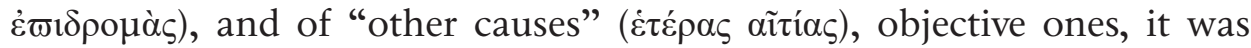
no longer "possible for the Primates of the Churches (oì $\tau \tilde{\omega} v \dot{\varepsilon} \kappa \kappa \lambda \eta \sigma i \tilde{\omega} v$

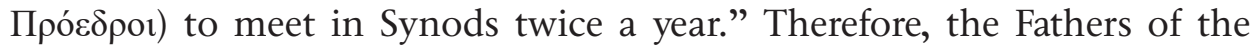
Sixth Ecumenical Synod (Constantinople, 691/692) provided for the obligation of the metropolitan Synod to meet, "in every eparchy," at least "once a year," in order to examine and solve "church affairs..." (can. 8). ${ }^{35}$

With the can. 6, the Fathers of the Seventh Ecumenical Synod (Nicaea, 787) "renewed" the decision made by the Fathers of the Sixth Ecumenical Synod (Trullan), ${ }^{36}$ which required the metropolitan synod to meet at least once a year due to same objective causes invoked by them.

From the text of the same canon of the Seventh Ecumenical Synod, we can also mention the fact that the metropolitan Synod met "for canonical

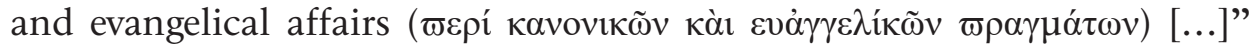
(can. 6 Sin. VII Ec.). ${ }^{37}$ Moreover, from the text of the same canon of the last Ecumenical Synod (Nicaea, 787) we can notice that - at that time - some metropolitans behaved despotically at times, hence the disposition of the Fathers of this ecumenical Synod that "the metropolitan

${ }^{32}$ Ibidem, p. 693.

33 Ibidem.

${ }^{34}$ Ibidem, p. 77.

35 Athenian Syntagma..., vol. II, pp. 324-325; The Canons of the Orthodox Church (Canoanele Bisericii Ortodoxe)..., 1992, pp. 108-109.

${ }^{36}$ About the Ecumenicality of this Synod, see N. V. DuRĂ: The Ecumenicity of the Council in Trullo: Witnesses of the Canonical Tradition in the East and the West. In: The Council in Trullo Revisited, coord. G. Nedungatt, M. Featherstone, Roma, 1995, pp. 229-262.

37 Apud Athenian Syntagma..., vol. II, p. 577. 
should not be allowed to ask the bishop for what he brings with him, be it animal or something similar. If it should be proven to be doing this, he should return it fourfold ( $\tau \varepsilon \tau \rho \alpha \varpi \lambda \alpha ́ \sigma 10 v) " 38$ (can. 6 Sin. VII Ec.).

As the Byzantine canonists (Zonara, Balsamon, and Aristen) remarked in their comment on this canon, the metropolitan is not "canonically justified" to do "such things," and if he does such things, he is to "pay fourfold." 39

\section{The metropolitan Synod, a peremptory reality in the life of the Eastern Orthodox Church of our days}

That the metropolitan Synod was a peremptory reality in the life of the Eastern Orthodox Church, of illo tempore, it attested just by can. 6 of the same ecumenical Synod (Nicaea, 787), from which we find out "that during the Seventh Ecumenical Synod, the metropolitan territory unit was also called diocese," ${ }^{40}$ that is eparchy. In fact, the ecclesiastical territorialorganisation system, of metropolitan type, has never disappeared from the life of the Orthodox Church, being indeed a reality in all local Orthodox Churches until our days.

On this regard, the Statute for the Organisation and Functioning of the Romanian Orthodox Church $^{41}$ remains an evident example. According to this Statute, the Romanian Orthodox Church is "autocephalous and unitary in its organisation" (art. 2), and "it has a hierarchical synodal leadership" (art. 3, par. 1). "The Romanian Patriarchate comprises the bishoprics (archbishops and bishops) grouped together in Eparchies, [...]" (art. 6, par. 2) and "in canonical and administrative terms, dioceses and archdioceses are grouped into eparchies [...] led by a metropolitan" (art. 110 , par. 1 and 2), who is the "canonical protos of a Metropolitanate, and who exercises the rights and performs the duties laid down by the Holy Canons, the Church Tradition and the present Statute" (art. 114, par. 1).

Regarding the metropolitan Synod, the same Statute of the Romanian Orthodox Church stipulates that it "coordinates the joint activities

${ }^{38}$ Ibidem, p. 578.

${ }^{39}$ Ibidem, pp. 578, 579, 580.

40 The Canons of the Orthodox Church (Canoanele Bisericii Ortodoxe)..., 1992, p. 167.

${ }^{41}$ Romanian Patriarchate. Statute for the Organization and Functioning of the Romanian Orthodox Churches (Patriarhia Română. Statutul pentru organizarea și funcționarea Bisericilor Ortodoxe Române). Ed. IBMBOR, Bucharest, 2008. 
of the dioceses in the Metropolitanate, within the boundaries set by the Holy canons, as well as by the statutory and regulatory norms in force" (art. 111 par. 2), and that it "is chaired by the metropolitan, who summons it whenever necessary" (art. 112, par. 1), but "the Metropolitan Synod," made up of "archbishops, bishops, bishops vicars and hierarch vicars of the eparchy" (art. 111 par. 1), is the one which "takes decisions by a half plus one of the votes of the number of members present" (art. 112, par. 2$) .42$

Therefore, the Metropolitan Synod is indeed a peremptory reality in the life of the Romanian Orthodox Church, as it is in fact in the life of each Orthodox Church of our days.

\section{The ancientness of the ordination as a bishop, the only criterion for the "precedence in honour" of a "primate"}

In Africa Proconsularis, the privilege of "the precedence in honour" (cf. can. 7 Sin. I Ec.) was recognised for the African bishops not due to the fact that they had their Sees in the metropolis of the provinces, but only due to their "ancientness" of the Episcopal ordination. In fact, this "Church rule was observed - attested the Fathers of the African Church always" (can. 86 Carthage). ${ }^{43}$

Therefore, in the Church of North Africa, this "ancientness" did not regard neither the "old age of the bishop" (can. 86 Carthage), nor the political importance of the cities of their Sees, but only the seniority of the ordination as a bishop.

By observance of this canonical principle of the ancientness of the Episcopal ordination, in the Church of Africa Proconsularis "the affirmation of the principle of the adoption and adaptation of the Church to the administrative-political system of the Roman Empire, [...], did not replace and distort the old apostolic principle according to which the importance and the primacy of the episcopal Sees were due only to the date of their establishment." This would also explain the fact that, "according to the old local, canonical custom" (African one), "the bishops' Synods were not presided - as mentioned by Nicolae V. Dură — by the metropolitan of the diocese (province), but by the elder bishop. ${ }^{44}$

42 Ibidem, p. 73.

${ }^{43}$ Athenian Syntagma..., vol. III, pp. 514-515.

${ }^{44}$ N. V. Dură: Le Régime de la synodalité..., p. 423. 
This ecclesiological reality is encountered not only in the case of the general Synod, chaired by the bishop of Carthage, who had its episcopal See in the Africa Proconsularis' capital, but also in the local Synods from the other provincial capitals of Africa Proconsularis. Indeed, in this African geographical area, the Churches of Numidia, Mauritania, Byzacena, Tripolitania, Arzuitania, Centuria, etc. had their "own primate" (primus) (cf. can. 17 Carthage), ${ }^{45}$ and their own Synod, and their primates had to participate - by virtue of the "old custom" of the place - to the "General Synod," that is, of the entire Africa.

The fact that the Primate of the Africa Proconsularis Church did not have a metropolitan at its head, "only the bishop of the First See" (can. 39 Carthage), ${ }^{46}$ that is, of the See of Africa Proconsularis, did not exempt it from the institution of synodality, on the contrary, in the text of the Codex Canonum Ecclesiae Africanae - which Romanian ancestor Dionysius Exiguus, ${ }^{47}$ who was counselor to eight Pontiffs of Rome, ${ }^{48}$ inserted into his canonical Collection - numerous references are made to both the "Great Synod" of the African Church, and to the Synods of each local Church, from its various provinces, with the exclusive duty of "the head of that diocese, together with the determined number of bishops, to decide what to do" (can. 26 Carthage). ${ }^{49}$ If necessary the Primate of that Church could "call as witnesses at least the neighbours" (can. 26 Carthage), ${ }^{50}$ that is, the bishops of the neighbouring local Churches.

At the suggestion of some Primates of local Churches to which the Primate of the African Church (Proconsularis) consented, in the person of the Primate of Carthage, Bishop Aurelius - who presided over the Synod totius Ecclesiae Africae - the Fathers of such a Synod ordered those who "although they were summoned to come to the Synod several times, they

45 The Canons of the Orthodox Church (Canoanele Bisericii Ortodoxe)..., 1991, p. 234.

${ }^{46}$ Ibidem, p. 242.

47 See N. V. Dură: Romanian Ancestor Dionysius Exiguus and his Canonical Work. A Canonical Evaluation of his Contribution to the Development of Church Law (Străromânul Dionisie Exiguul şi opera sa canonică. O evaluare canonică a contribuției sale la dezvoltarea Dreptului bisericesc). "Ortodoxia”, XLI, 4 (1989), pp. 37-61; IDEM: Denis Exiguus (Le Petit) (465-545). Précisions et correctifs concernant sa vie et son oeuvre. "Revista Española de Derecho Canonico", L (1993), pp. 279-290; N. V. Dură, C. Mititelu: L'École roumaine du Droit canonique et sa contribution au développent du Droit canonique de l'Eglise Orthodoxe Ecuménique. In: Tradiție şi continuitate în teologia tomitană. Două decenii de învățământ teologic universitar la Constanța (1992-2012). Ed. Arhiepiscopiei Tomisului, Constanța, 2012, pp. 37-60.

${ }^{48}$ N. V. Dură: Dionysius Exiguus and the Popes of Rome (Dionisie Exiguul şi Papii Romei). "Biserica Ortodoxă Română”, CXXI, 7-12 (2003), pp. 459-468.

49 The Canons of the Orthodox Church (Canoanele Bisericii Ortodoxe)..., 1991, p. 237.

${ }^{50}$ Ibidem. 
refused, relying on their own people [...]" (cf. can. 53 Carthage) $)^{51}$ and on the connivance with the governors of the state power they established "new dioceses [...] not to keep their See," and "to lose those lands [...], in the same way as some who are rebellious" (can. 53 Carthage).

In one of the Synods of the African Church, it was in fact ordered that any clergyman who was "condemned by the bishops," that is, the Synod, could neither "be absolved by the Church whose servant he was, nor by any kind of man," including the "emperor" (can. 62 Carthage). ${ }^{52}$

The same Synod stipulated expressly that the Bishops obey the "judgment of the Synod" (can. 87),,$^{53}$ but not only of the General Synod, that is, "of the entire Africa," but also of the "Synods of their own dioceses" (can. 95 Carthage), ${ }^{54}$ that is, the "Synods of Africa" (can. 125 Carthage), ${ }^{55}$ as a bishop cannot judge his own cause, cannot "pass sentence on his own court issues" (can. 107 Carthage). ${ }^{56}$

Similar situations are found in other local Churches, even within the geographical area of the Roman Empire, and even much later, as for example in the Church of the Iberian Peninsula, where "the Acts of the Synods have always been signed, first of all, by the elder bishop and not by the metropolitan." 57

Actually, the fact that the eparchial, metropolitan type of organisation, was not adopted in the entire Roman empire area, is, thus, emphasised in a peremptory way, not only by the reality of the Church of Africa Proconsularis, which maintained its form of initial organisation since the time of St. Cyprian of Carthage († 257), that is, the establishment of local Churches that respected both the ethnic and the geographic criteria, but also by other national Churches in western Europe, such as the Iberian Peninsula.

\footnotetext{
51 Ibidem, pp. 248-249.

52 Ibidem, p. 253.

${ }^{53}$ Ibidem, pp. 262-263.

${ }^{54}$ Ibidem, pp. 266-267.

55 Ibidem, p. 277.

${ }^{56}$ Ibidem, pp. 270-271.

${ }^{57}$ N. V. Dură: Le Régime de la synodalité..., p. 423.
} 
7. The eparchial (metropolitan) Synod, in its two aspects of manifestation: as a "complete synode" and as a "restricted synode"

From the canonical legislation of the Eastern Church in the first millennium, however, it can be noted that the eparchial (metropolitan) Synod was a "complete Synod," that is, of the entire diocese, made up of all the bishops of that Church province (cf. can. 37 apost.; 4 Sin. I Ec.).

The same canonical legislation also makes a reference to a limited "metropolitan Synod." In regard to this reality, the first testimony dates back to about 15-16 years after the First Ecumenical Synod, namely from the Synod assembled in Antioch (340/341), which distinguishes between the "Complete Synod" and the "Restricted Synod."

Indeed, the Fathers of this local Synod (Antioch, 340/341) used "for the first time" both the syntagma "Complete Synod" and "Restricted Synod." And, according to the testimony which they gave to us, " $\dot{\eta} \tau \varepsilon \lambda \varepsilon i ́ \alpha$

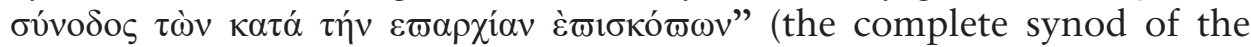
province's bishops) had - among other things - as its main competences "the excommunication" (cf. can. 17) and the judgment of a bishop for grave causes (cf. can. 18 Antioch), ${ }^{58}$ etc.

In Latin, such a "synod," that is, a "Complete Synod," was expressed using the syntagm concilium perfectum, ${ }^{59}$ and in one of the old canonical Collections of the Church of Rome, ${ }^{60}$ namely in "Prisca," the word

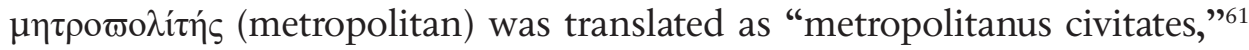
which prove the fact that, in the western Church, of that time, the metropolitan system lived together with the ethnical (national) one, as it is attested both in the De modo celebrandi concilium treaty, drawn up by the Fourth Synod of Toledo (Spain) in 633, and "in its subsequent versions," in which we find expressly reference to "the assembly of an eparchial or national synod" under the presidency of a metropolitanus episcopus, ${ }^{62}$ that is, a metropolitan.

In the Africa Proconsularis Church, the Synod, which had as a specific task the judgment of the clergymen of the church institution (bishop,

${ }^{58}$ Ibidem, p. 424.

59 Ibidem.

${ }^{60}$ See N. V. DuRĂ: Canonic, Western Collections of the First Millennium (Colecții canonice, apusene, din primul mileniu). "Analele Universității Ovidius. Seria: Drept şi Ştiințe Administrative", 1 (2003), pp.19-33.

${ }^{61}$ IDEM: Le Régime de la synodalité..., p. 434.

${ }^{62}$ Ibidem, p. 435. 
priest, and deacon), was perceived and defined as a "Restricted Synod" (cf. can. 5, 12 Carthage), which it was chaired by the Principle of the local Church, while the "Complete Synod" was chaired by the Bishop of Carthage (can. 14), which was indeed primas Sedis totius Ecclesiae Africanae (the first See of the entire African Church).

\section{Is there so-called crisis of synodality in our Churches?}

That in our Churches there is no "crisis of synodality" whatsoever is proved not only by the peremptory reality of their regime of the synodality, by also by their canonical legislation, both from the Syntagma Canonum of the Easter Orthodox Church, and by the Code of Canon Law of the Roman-Catholic Church.

Indeed, even in the Code of Canon Law — promulgated in 1983 - it is expressedly mentioned that provincia ecclesiastica ipso iure personalitate iuridica gaudet (an ecclesiastical province possesses juridic personality by the law itself) (can. $432 \S 2$ ), and that "the provincial council (concilium provinciale) and the metropolitan (Metropolita) possess authority (auctoritate) in an ecclesiastical province (in provincial ecclesiastica) according to the norm of law" (can. $432 \S 1$ ).

Moreover, the canons of this Code, which "regard only the Latin Church" (can. 1), that is of "the Roman Catholic Church," consisting "of twenty two autonomous (sui iuris) Churches, [...], united under the leadership of the bishop of Rome, the pope,"63 prove à l'évidence that the provincial Council it is "l'unique institution synodale qui soit restée substantiellement identique à elle-même au profil original de presque deux millénaires," despite of the fact that both in the Western Churc, and in the Eastern Church, we could still find a "différence entre la norme canonique concernent la fréquence des Concile provinciaux et la pratique instaurée dans chacune de leur époques [...]."64

Although through the eparchial (metropolitan) Synod, stipulated by the Fathers of the First Ecumenical Synod (cf. can. 4, 6, 7), it was in fact affirmed the whole synodal system, however, some ecclesiologists of the Eastern Church alleged that, in its area, we are basically dealing with

${ }^{63}$ J. M. Huels, o. S. M.: Introductory Canons (cc. 1-6). In: New Commentary on the Code of Canon Law, ed. by J. P. Beal et al., Ed. Paulist Press, New York, 2000, p. 49.

${ }^{64}$ Vescovi e Conferenze episcopali. "Ephemerides Juris Canonici”, 1-2 (1991), p. 140, apud N. V. Dură: Le Régime de la synodalité..., p. 436. 
"a crisis of synodality and at the level of dioceses," ${ }^{65}$ which would have its basis in the ecclesiological and canonical reality of this Church.

That there is not a so-called crisis of eparchial synodality is confirmed by the very fact that the institution of synodality, of metropolitan type, is still present in all Orthodox Churches of today, ${ }^{66}$ being regulated by the same canonical bases established in the first millennium (from the 4th to 9th centuries) (cf. can. 37 and 74 apost.; 4, 5, 6 Sin. I Ec.; 2, 6 Sin. II Ec.; 8 Sin. III Ec.; 1, 9, 19 Sin. IV Ec.; 17 Sin. VI Ec.; 1, 8 Sin. VI Ec.; 1, 6 Sin. VII Ec.; 14, 15, 17 Antioch; 40 Laodicea; 6 Sardica; 73 and 76 Carthage; 1 Constantinople (394) etc.).

It is true, however, that during the centuries (cf. can. 9, 17, 28 Sin. IV Ec.), such an eparchial, metropolitan, "crisis of synodality" was manifested - even if only ephemerally - sometimes caused by the nonobservance of the canonical rules regarding the procedures of assembling and conducting the works of the eparchial Synod in a collegialiter and synodaliter way, and, ipso facto, due to the assertion of some hegemonic claims by the presiding persons themselves, that is, by some metropolitan, exarchs or patriarchs.

The documentary testimonies - historical and canonical - empha-

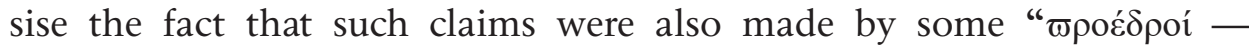
antistes" (primates) ${ }^{67}$ of some local, autocephalous Churches, organised as Exarchates or Patriarchates.

It should also be recalled that during the (Eastern and Western) Roman Empire period, some of these antistes claimed their protia (primacy) not because of the apostolicity of their See, but because of the political importance of the citadel where they had their See, etc. This would also explain the fact that, even from the time of the First Ecumenical Synod (Nicaea, 325), the "metropolitan," that is, the bishop of the province's metropolis, claimed their "right of veto over all synodal decisions", an ecclesiological reality confirmed, in fact, "by canon 6 of the first ecumenical synod (Nicaea, 325)."68

${ }^{65}$ M. Stavrou: Linéaments d'une Théologie orthodoxe de la conciliarité. "Irenikon", 4 (2003), p. 471.

${ }^{66}$ For instance, see The Statute for the Organization and Functioning of the Romanian Orthodox Church (Statutul pentru organizarea și funcționarea Bisericii Ortodoxe Române)..., art. 111-114..., pp. 72-75.

${ }^{67}$ See N. V. DuRĂ: The Protos in the Romanian Orthodox Church according to its Modern Legislation. “Kanon”, IX (1989), pp. 139-161; IDEм: Political-Juridical and Religious Status of the Romanian Countries and the Balkan People during the 14th-19th Centuries. "Revue des Études Sud-Est Européennes", XXVII, 1-2 (1989), pp. 159-170.

${ }^{68}$ M. Stavrou: L'autorité ecclésiale dans le monde byzantine. "Contacts”, 202 (2003), p. 155. 


\section{The metropolitan rights according to the canons of the Council of Sardica (343)}

According to the "metropolitan's primary right" — stipulated by the First Ecumenical Synod - no one could "become a bishop without the metropolitan's consent" (can. 6 Sin. I Ec.). ${ }^{69}$ However, until the epoch of the First Ecumenical Council (Nicaea, 325), the bishop's primacy right in the respective province - in which the Church constituted in an ethnic setting usually existed (cf. can. 34 apost.) - was not one of a jurisdictional nature, but only honorary one.

The Fathers of the Synod of Sardica (343) decided that, "in the event of a conflict between a bishop and his metropolitan," the possibility of an appeal to the bishop of Rome would be established (cf. can. 5), but according to the opinion of an Orthodox ecclesiologist - " [...] the powers of Rome were limited to holding a re-examination of the case, with the participation of bishops from the neighboring provinces [...]." ${ }^{10}$

Concretely, here is what the Fathers of the Council of Sardica decided in their canon: "[...] if any bishop is accused, and the bishops of the

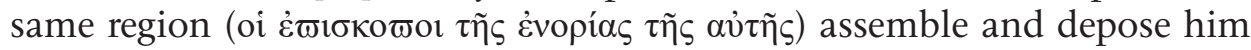
from his office, and he appealing, so to speak, takes refuge with the most

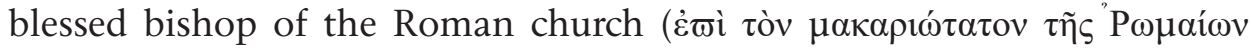
$\left.\dot{\varepsilon} \kappa \lambda \lambda \eta \sigma^{\prime} \alpha \varsigma\right)$, and he be willing to give him a hearing, and think it right to renew the examination of his case, let him be pleased to write to those fellow-bishops who are nearest the province ( $\tau \tilde{\eta} \dot{\varepsilon} \omega \alpha \rho \chi i \alpha)$ that they may examine the particulars with care and accuracy and give their votes on the matter in accordance with the word of truth. And if any one require that his case be heard yet again, and at his request it seem good to move the

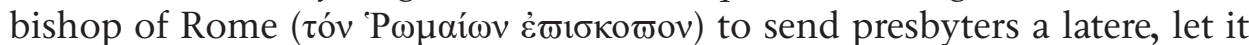
be in the power of that bishop, according as he judges it to be good and decides it to be right - that some be sent to be judges with the bishops and invested with his authority by whom they were sent. And be this also ordained. But if he think that the bishops are sufficient for the examination and decision of the matter let him do what shall seem good in his most prudent judgment" (can. 5 Sardica). ${ }^{71}$

${ }^{69}$ Canon 6 of the First Ecumenical Synod (Nicaea, 325). In: Athenian Syntagma..., vol. II, p. 128.

${ }^{70}$ M. Stavrou: L'autorité ecclésiale dans le monde byzantin..., pp. 155-156.

${ }^{71}$ Select Library of the Nicene and Post-Nicene Fathers..., p. 1010; Athenian Syntagma..., vol. II, pp. 239-240. 
According to the opinion of the Byzantine canonists of the 12th century (Zonara, Balsamon, and Aristen), in the text of the can. 5 of the Council of Sardica it was in fact invoked as a panel the "Synod of neighbouring bishops," and the appeal to the bishop of Rome was limited to "renewing judgment" through this Synod. ${ }^{72}$

Some of the western canonists remarked however the fact that, in this canon (the Fifth Council of Sardica), "there is properly speaking no provision for "appeal," which entirely suspends [i.e. by the canon law] the execution and effect of the first sentence; but rather for a revision of judgment [...]; those who were sent by the Roman bishop from his side (a latere) or the bishops wire were appointed, ought, together with the bishops of the province who had given the former sentence, to give a fresh judgment and declare their sentence." 73

Therefore, "in honour of the memory of St. Peter Apostle" (can. 5 Sardica) - the Protos of the Apostles - the synodal Parents decided that if a bishop considered his metropolitan to have been proven biased, and that he was unjustly condemned, then he should be entitled to appeal to the court of appeal, that is, to the Tribunal of the bishop of Rome, who decided the rejudgment of the case in the presence of bishops from the neighboring local Churches.

In can. 6, the Fathers of the Synod of Sardica stipulated also - among other things - "the way in which an appeal is tried, that is, the parties are required to agree that, within the patriarchate of Rome, the pope of Rome be empowered in a solemn manner as an appeal institution, entitled to reject or admit the claims of those who considered themselves wronged. Thus, should the application be rejected, the given sentence would remain valid, and in case of an exception of the request, send a request to re-try the case in a court composed of neighboring bishops, other than those who tried the case in the first instance, but certainly belonging to the same Metropolitanate." 74

That such unrighteous judgments were frequent in the church world at that time is confirmed by the Fathers of the First Ecumenical Synod

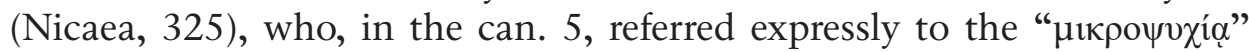

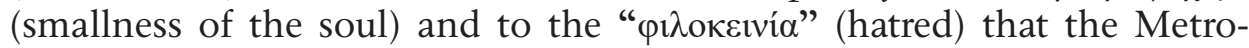
politan himself was capable of even within the metropolitan Synod, who also judged various discipline-related cases of the clergymen in his diocese (cf. can. 37 apost.).

${ }^{72}$ See Zonara, Balsamon and Aristen's Comments on can. 3 of the Synod of Sardica. In: Athenian Syntagma..., vol. III, pp. 234-238.

${ }^{73}$ Select Library of the Nicene and Post-Nicene Fathers..., p. 1011.

${ }^{74}$ Comments on Canon 3 of the Synod of Sardica. In: The Canons of the Orthodox Church (Canoanele Bisericii Ortodoxe)..., 1992, p. 233. 


\section{In lieu of conclusions}

From the careful examination of the text of the canonical legislation of the Eastern Church, it was obvious that the first form of synodality, as a canon-legal institution, manifested itself through the "eparchial (metropolitan) synod," whose canonical foundations were established by the Fathers of the First Ecumenical Synod (cf. can. 4, 6).

Moreover, it was noted and revealed the fact that in accordance with the canonical norms of the Eastern Church of the first millennium, the "primacy" or "primate" of the metropolitan was framed in the space of the synodality regime, despite of the fact that some metropolitans, who summoned and chaired the provincial synods, proved to have sometimes biased attitude in their judgments, hence the correctives taken - over the centuries - by the Fathers of the Holy Synods for their wrong behaviour (cf. can. 5 Sin. I Ec.; 5 Sardica etc.).

It can be also retained the fact that, according to the provisions of the canonical legislation of the Eastern Church, to this type of synod "belonged both to jus ordinandi and to jus judicandi, i.e. to the right to ordain and judge the clergymen of that province." 75

Therefore, we can conclude that the metropolitan had not only the right to confirm the election and the ordination of the bishops in his diocese (cf. can. 4 Sin. I Ec.), but also the canonical duty of being "an executant of the synodal decisions." $"$ 6

This reality will become especially evident at the end of the 4th century, that is, after the entrance of the ecclesiastical provinces into the jurisdictional-canonical area of the superior administrative-territorial unit, that is, the "Exarchate" (cf. can. 2, 3, 6 Sin. II Ec.), and - after its disappearance in the 6th century - by the transfer of the Metropolitanates under the direct jurisdiction of a superior administrative-territorial church unit, known as the "Patriarchate."77

${ }^{75}$ N. V. Dură: Le Régime de la synodalité..., p. 437.

76 D. Salachas: Le "status" ecclésiologique et canonique des Eglises Catholiques Orientales "sui iuris" et des Eglises Orthodoxes autocéphales. "L'Année canonique", 33 (1990), p. 39, apud N. V. Dură: Le Régime de la synodalité..., p. 437.

77 See N. V. Dură, C. Mititelu: Canonical Legislation and European Legal-Canonical Institutions in the First Millennium (Legislația canonică şi instituțiile juridico-canonice europene, din primul mileniu). Ed. Universitară, Bucharest, 2014; IDEM: The State and the Church in IV-VI Centuries. The Roman Emperor and the Christian Religion. In: SGEM Conference on Political Sciences, Law, Finance, Economics \& Tourism, I (2014), Albena, pp. 923-930; N. V. DuRĂ: Patriarch and the Patriarchate. The Patriarchate, one of the Ancient European Institutions (Patriarh şi Patriarhie. Patriarhia, una din vechile Instituții europene). "Biserica Ortodoxă Română”, CIII, 1-3 (2005), pp. 414-432; IDEM: The Cen- 
And, even in our days, both in the Eastern Orthodox Church and in the Old Oriental Churches (Non-Chalcedonies), ${ }^{78}$ the Synod is "the highest authority" (Article 11 of The Statute of the Romanian Orthodox Church) in any Church "organised as Patriarchate" (Article 6, par. 1, of The Statute of the Romanian Orthodox Church), and its "central deliberative body" (Article 9 of The Statute of the Romanian Orthodox Church).

Naturally, all these ecclesiological and canonical testimonies abundantly confirm that, in the Eastern Orthodox Church, both the Synod of the metropolitan See - whose bases or canonical foundations claim their origin in the decisions made by the Holy Fathers of the First Ecumenical Synod (cf. can. 4, 5, 6, 7) - and the national Synod of an autocephalic Church, were and are a peremptory reality.

tral and Local Executive Bodies of the Romanian Orthodox Church and their Managerial Activity (Organismele executive centrale şi locale ale Bisericii Ortodoxe Române şi activitatea lor managerial). In: Contribuții la conturarea unui model românesc de management, coord. I. Petrescu, Ed. Expert, Bucharest, 2014, vol. II, pp. 413-447.

${ }^{78}$ For instance, in the Old Eastern or Neochalcedonian Churches. See N. V. DuRĂ: The Synod of Chalcedon in the Dogmatic Tradition of the Ethiopian Church (Sinodul de la Calcedon în Tradiția dogmatică a Bisericii etiopiene). "Ortodoxia”, XXVII, 3 (1975), pp. 459-464; IDEM: The Anaphoras (liturgical canons) of the Ethiopian Church. The Process of their Emergence and Development (Anaforalele (canoane liturgice) Bisericii etiopiene. Procesul apariției și dezvoltării lor). "Studii Teologice”, XXIX, 7-10 (1977), pp. 589599; IDEM: The Evangelization of Ethiopia (Evanghelizarea Etiopiei). "Studii Teologice", XXX, 1-2 (1978), pp. 81-91; IDEM: The Theological Dialogue between the Orthodox Church and the Old Eastern Churches. Results and Perspectives (Dialogul teologic intre Biserica Ortodoxă şi Bisericile Vechi Orientale. Rezultate şi Perspective). In: Autocefalie şi comuniune. Biserica Ortodoxă Română în dialog şi cooperare externă (1885-2010), Ed. Basilica, Bucureşti, 2010, pp. 272-297.

\section{Bibliography}

Canons of the Orthodox Church. Notes and comments (Canoanele Bisericii Ortodoxe. Note şi comentarii), ed. I. N. Floca, Sibiu, 1991 and 1992.

Dură N. V.: "Scythia Mynor" (Dobrudja) and her Apostolic Church. The Archiepiscopal and Metropolitan See of Tomis (4th-14th-centuries) („Scythia Mynor” (Dobrogea) şi Biserica ei apostolică. Scaunul arhiepiscopal şi mitropolitan al Tomisului (sec. IV-XIV)). Ed. Didactică şi Pedagogică, Bucharest, 2006.

DurĂ N. V.: Canonic, Western Collections of the First Millennium (Colecții canonice, apusene, din primul mileniu). "Analele Universității Ovidius. Seria: Drept şi Ştiințe Administrative”, 1 (2003), pp. 19-33. 
Dură N. V.: Christianism in Pontic Dacia. The „Scythian Monks” (Daco-Roman) and their Contribution to the Advance of Ecumenical Unity and the Development of the European Christian Humanist Culture. "Revue Roumaine d'Histoire", 1-4 (2003), pp. 5-18.

Dură N. V.: Denis Exiguus (Le Petit) (465-545). Précisions et correctifs concernant sa vie et son oeuvre. "Revista Española de Derecho Canonico", L (1993), pp. 279-290.

Dură N. V.: Didascalia, the Ethiopian Version (Didascalia, versiunea etiopiană). “Studii Teologice", XXVII, 5-6 (1975), pp. 436-451.

Dură N. V.: Dionysius Exiguus and the Popes of Rome (Dionisie Exiguul şi Papii Romei). "Biserica Ortodoxă Română”, CXXI, 7-12 (2003), pp. 459-468.

Dură N. V.: Le Régime de la synodalité selon la législation canonique, conciliaire, oecuménique, du I ${ }^{e r}$ millénaire, Ed. Amethyst 92, Bucharest, 1999.

Dură N. V.: Patriarch and the Patriarchate. The Patriarchate, one of the Ancient European Institutions (Patriarh şi Patriarhie. Patriarhia, una din vechile Instituții europene). “Biserica Ortodoxă Română”, CIII, 1-3 (2005), pp. $414-432$.

Dură N. V.: Political-Juridical and Religious Status of the Romanian Countries and the Balkan People during the 14th-19th Centuries. "Revue des Études Sud-Est Européennes”, XXVII, 1-2 (1989), pp. 159-170.

Dură N. V.: Romanian Ancestor Dionysius Exiguus and his Canonical Work. A Canonical Evaluation of his Contribution to the Development of Church Law (Străromânul Dionisie Exiguul şi opera sa canonică. O evaluare canonică a contribuției sale la dezvoltarea Dreptului bisericesc). "Ortodoxia”, XLI, 4 (1989), pp. 37-61.

Dură N. V.: The Anaphoras (liturgical canons) of the Ethiopian Church. The Process of their Emergence and Development (Anaforalele (canoane liturgice) Bisericii etiopiene. Procesul apariției şi dezvoltării lor). "Studii Teologice”, XXIX, 7-10 (1977), pp. 589-599.

DURĂ N. V.: The Appropriation of the Canons in the Ethiopian Church (Receptarea canoanelor în Biserica etiopiană). "Studii Teologice", XXVII, 3-4 (1975), pp. $277-289$.

Dură N. V.: The Canonical, Fundamental, Organizing and Functioning Principles of the Orthodox Church and their Reflection in the Legislation of the Romanian Orthodox Church (Principiile canonice, fundamentale, de organizare şi funcționare a Bisericii Ortodoxe şi reflectarea lor în legislația Bisericii Ortodoxe Române). "Revista de Teologie Sfântul Apostol Andrei”, V, 9 (2001), pp. 129-140.

DurĂ N. V.: The Central and Local Executive Bodies of the Romanian Orthodox Church and their Managerial Activity (Organismele executive centrale şi locale ale Bisericii Ortodoxe Române şi activitatea lor managerial). In: Contribuții la conturarea unui model românesc de management, coord. I. Petrescu, Ed. Expert, Bucharest, 2014, vol. II, pp. 413-447.

DurĂ N. V.: The Church of Alexandria and the Canonical-Pastoral Activity of its Hierarchs until the Council of Chalcedon (Biserica Alexandriei şi activitatea 
canonico-pastorală a ierarhilor ei până la Sinodul de la Calcedon) (451). "Studii Teologice", XXXIII, 1-2 (1981), pp. 5-25.

Dură N. V.: The Churches of Europe and the "European Union". Ecumenism, Christian Reconciliation and European Unity (Bisericile Europei şi „Uniunea Europeană”. Ecumenism, reconciliere creştină şi unitate europeană). In: Biserica în misiune. Patriarhia română la ceas aniversar, Ed. IMBOR, Bucharest, 2005, pp. 771-794.

DurĂ N. V.: The Coptic Church and its Organization in Light of the Testimonies of the Historical-Aghiographic Tradition (Biserica Coptă şi organizarea ei în lumina mărturiilor Tradiției istorico-aghiografice). "Studii Teologice", XXXIV, 3-4 (1982), pp. 200-219.

Dură N. V.: The Ecumenicity of the Council in Trullo: Witnesses of the Canonical Tradition in the East and the West. In: The Council in Trullo Revisited, coord. G. Nedungatt, M. Featherstone, Roma, 1995, pp. 229-262.

DurĂ N. V.: The Edict of Milan (313) and its Impact on the Relations between the State and the Church. Some Historical, Legal and Ecclesiological Considerations (Edictul de la Milan (313) şi impactul lui asupra relațiilor dintre Stat şi Biserică. Câteva considerații istorice, juridice şi ecleziologice). "Mitropolia Olteniei", 5-8 (2012), pp. 28-43.

Dură N. V.: The Ethiopian Canonical Collection (Corpus Juris Canonici Aethiopici) (Colecția canonică etiopiană (Corpus Juris Canonici Aethiopici)). "Studii Teologice", XXVI, 9-10 (1974), pp. 725-738.

DurĂ N. V.: The Ethiopian Church and its Liturgical Anaphoras (Biserica etiopiană şi „Anaforalele” ei liturgice). "Revista de Teologie Sfântul Apostol Andrei”, XII, 1 (2008), pp. 9-45.

Dură N. V.: The Evangelization of Ethiopia (Evanghelizarea Etiopiei). "Studii Teologice", XXX, 1-2 (1978), pp. 81-91.

DurĂ N. V.: The Organization of the Ethiopian Church and its Canonical Foundations (Organizarea Bisericii etiopiene şi bazele ei canonice). Ed. IBMBOR, Bucharest, 1990.

Dură N. V.: The Primate in the Orthodox Church. Canonic Study (Întâistătătorul in Biserica Ortodoxă. Studiu canonic). "Studii Teologice”, XL, 1 (1988), pp. $15-50$.

Dură N. V.: The Protos in the Romanian Orthodox Church according to its Modern Legislation. “Kanon”, IX (1989), pp. 139-161.

DurĂ N. V.: The Relationships between the State and the Church and their Legal Regime. Rules of International and National Law. "Bulletin of the Georgian National Academy of Sciences", XII, 4 (2018), pp. 192-201.

Dură N. V.: The Synod of Chalcedon in the Dogmatic Tradition of the Ethiopian Church (Sinodul de la Calcedon în Tradiția dogmatică a Bisericii etiopiene). “Ortodoxia”, XXVII, 3 (1975), pp. 459-464.

DurĂ N. V.: The Theological Dialogue between the Orthodox Church and the Old Eastern Churches. Results and Perspectives (Dialogul teologic intre Biserica Ortodoxă şi Bisericile Vechi Orientale. Rezultate şi Perspective). In: Autocefalie şi comuniune. Biserica Ortodoxă Română în dialog şi cooperare externă (1885-2010). Ed. Basilica, Bucureşti, 2010, pp. 272-297. 
Dură N. V., Mititelu C.: Canonical Legislation and European Legal-Canonical Institutions in the First Millennium (Legislația canonică şi instituțiile juridicocanonice europene, din primul mileniu). Ed. Universitară, Bucharest, 2014.

Dură N. V., Mititelu C.: L'École roumaine du Droit canonique et sa contribution au développent du Droit canonique de l'Eglise Orthodoxe Ecuménique. In: Tradiție şi continuitate în teologia tomitană. Două decenii de învățământ teologic universitar la Constanța (1992-2012), Ed. Arhiepiscopiei Tomisului, Constanța, 2012, pp. 37-60.

Dură N. V., Mititelu C.: The Freedom of Religion and the Right to Religious Freedom. In: SGEM Conference on Political Sciences, Law, Finance, Economics \& Tourism, I (2014), Albena, pp. 831-838.

DurĂ N. V., Mititelu C.: The State and the Church in IV-VI Centuries. The Roman Emperor and the Christian Religion. In: SGEM Conference on Political Sciences, Law, Finance, Economics \& Tourism, I (2014), Albena, pp. 923930.

Kvesitadze G., Dură N. V.: The Roots of the Georgian and Romanian Science and Culture, Ed. Academiei Oamenilor de Ştiință din România, Bucharest, 2017.

Mititelu C.: Dacian-Roman Cultural Personalities from Scythia Minor (4th6th Centuries) and their Contribution to the Affirmation and Promotion of a Humanistic-Christian Culture at European Level. In: New Approaches in Social and Humanistic Sciences, 2018, Iasi-London, ed. V. Manolachi, C. Rus, S. Rusnac, pp. 316-331.

New Commentary on the Code of Canon Law, ed. by J. P. Beal et al., Ed. Paulist Press, New York, 2000.

Select Library of the Nicene and Post-Nicene Fathers of the Christian Church, ed. P. Schaff, H. Wace, 2nd series, vol. 14, SAGE Software Albany, Oregon, 1996, apud http://www.agape-biblia.org/orthodoxy/The\%20Seven\%20Ecu menical\%20Councils.pdf (accessed: 18.12.2018).

Statute for the Organization and Functioning of the Romanian Orthodox Churches (Statutul pentru organizarea și funcționarea Bisericilor Ortodoxe Române). Ed. IBMBOR, Bucharest, 2008.

Stavrou M.: L'autorité ecclésiale dans le monde byzantine. "Contacts", 202 (2003), pp. $148-179$.

Stavrou M.: Linéaments d'une théologie orthodoxe de la conciliarité. "Irenikon", 4 (2003), p. 470-505.

The Syntagma of the Divine and Sacred Canons (Athenian Syntagma), ed. G. A. Rhalli, M. Potli, vol. II-III, Atena, 1852-1853. 
CăTĂLINA Mititelu

\title{
Synode métropolitain et ses fondements canoniques Perspective orthodoxe
}

\begin{abstract}
Résumé
Le lecteur de cette étude aura l'occasion de se familiariser avec l'ancienne institution canonique et juridique européenne, c'est-à-dire la synodalité, notamment avec les dispositions des normes canoniques de l'Église d'Orient concernant l'institution éparchiale (métropolitaine) de la synodalité et, ipso facto, avec la question du système synodal. Comme les fondements canoniques du système synodal sont inclus dans la législation canonique du premier millénaire, nous avons dû faire une analyse herméneutique de son texte, ce qui nous a montré qu'en nous référant à ad fontes, nous pouvons aussi ouvrir une voie qui conduira à la restauration de l'unité des deux mondes chrétiens, c'est-à-dire de Pars Orientis et Pars Occidentis.
\end{abstract}

Mots clés: législation canonique, institutions de droit canoniques, synodes œcuméniques

\section{CĂTĂLINA Mititelu}

\section{Sinodo metropolitano e le sue basi canoniche Prospettiva ortodossa}

\begin{abstract}
Sommario
Il lettore di questo studio avrà l'opportunità di conoscere l'antica istituzione canonica e giuridica europea, cioè la sinodalità, e particolarmente le disposizioni delle norme canoniche della Chiesa d'Oriente relative all'istituzione eparchiale (metropolitana) della sinodalità e, ipso facto, la questione del sistema sinodale. Poiché le basi canoniche del sistema sinodale sono incluse nella legislazione canonica del primo millennio, abbiamo dovuto fare un'analisi ermeneutica del suo testo, il che ci ha mostrato che, facendo riferimento ad ad fontes, possiamo anche aprire una strada conducente al ripristino dell'unità dei due mondi cristiani, e cioè Pars Orientis e Pars Occidentis.
\end{abstract}

Parole chiave: legislazione canonica, istituzioni canoniche, sinodi ecumenici 